\title{
Language and Gender Analysis of Three Walt Disney Movies: A Study of Female Language Features of Three Princesses
}

\author{
Submitted By \\ Nariman Kamal Eldin Abd Elaziz Mahmoud \\ Master's Student \\ Faculty of Arts, Department of English Language \\ and Literature - Helwan University \\ narimankamal.eldin@outlook.com
}

\begin{abstract}
Gender portrayal of characters in Disney princesses' movies has been a rich topic of research by scholars, especially in the field of linguistics. Many studies examined the impact of these films on children's perception of gender and gender roles. Some papers concluded that there are many prevailing stereotypes in the portrayal of the female leading characters in the films. Utilizing qualitative and quantitative methods, the aim of this research is to study the language of three princesses from three films produced in three different periods of time. The research examines the use of women's language features introduced in the field of language and gender, with focus on seven of the features only. Results show significant change has happened in the discourse of the princesses towards progressively commanding language. Features that have been perceived as feminine disappeared gradually, and the verbal utterances of the three protagonists may have become more forceful.

Keywords: Women's language characteristics, gender roles, Disney Princesses
\end{abstract}




\section{Language and Gender Analysis of Three Walt Disney Movies}

The effects of media, regardless of its means, have been the main premise of discourse analysis research. Due to the power that the media holds with respect to affecting people's comprehension and perception of the society, there has been a lot of research directed to inspect the implied messages that can be conveyed through television programs and movies. This is particularly apparent in Disney princesses' movies that young girls view as role models, therefore; their portrayal must be inspected from a verbal perspective.

\section{Context of the Study}

Disney princesses' movies are the best material to examine the underlying gender stereotypes in children's motion picture films. The princess as a character has a history that goes back to the 1800s in the United States of America (FormanBurnell, 2009). It was used as a method for showing young girls how to be feminine (Forman-Burnell, 2009). Years later, Walt Disney introduced the princess's role in American popular culture with his very first film Snow White and the Seven Dwarves in the year 1973. Today, young girls imitate the princesses' style and way of speaking and use the character to play with one another (Cook \& Main, 2008).

The princess movies became very popular by the mid-2001 (Orenstein, 2006). Disney benefited from this expansion by making the Disney Princess Franchise- also known as "Princess Line" (Orenstein, 2006). It integrated a considerable lot of Disney's most popular princesses' films into one unified brand. For some researchers, this unification imposes intriguing ideological implications (Orenstein, 2006). The line joins all characters under what Orenstein (2006) calls princess ethos, which keeps all imperial role models from as far back as 1937 pertinent to new ages (Forgacs, 1992; Do Rozario, 2004; Stover, 2013). The princess' films were seen connected to female gender execution. Not just that, Disney has also been effectively attempting to camouflage their princesses' animated films with unbiased titles and male co-stars to get young men to connect with the movies (Wilde, 2014).

\section{Objective of the study}

This study examines the following three films: Snow White and the Seven Dwarves (1937), Beauty and the Beast (1991), and Rapunzel (2010). The selected films are from three different eras. Change in the language of the princesses is hypothesized to have become more commanding, and that this shift validates hypotheses from the field of language and gender research. This study uses quantitative and qualitative methods to generate a clear view of the change in the female protagonists' utterances. It attempts to look in-depth at the ways certain female verbal stereotypes are constructed in the female characters' speeches, by 
examining seven female language features proposed in language and gender research to generate quantitative results.

\section{Research Questions}

The aim is to answer the following questions:

1-What are the changes in the verbal reactions of the three Disney female protagonists across the three eras?

1-a: How does the language change of the female characters corroborate theories from the field of language and gender?

\section{Significance of the Study}

This study fills the research gap by investigating three Disney films utilizing triangulated language and gender methodologies. This examination may convey imperative quantitative results to studies of females' depiction in youngsters' animated films.

\section{Literature Review}

For years, women were perceived by the society as fragile, and their discourse was inferior to men's. It was the main reason why many linguists around the globe studied female discourse with great enthusiasm. The earliest studies can be found as far back as 1922 on differences between the ways in which people talk (Litosseliti, 2006). Lakoff (1975), Tannen (1991), and Gray (1994), contributed to gender studies, and asserted the distinction between genders. Later perspectives, however, claimed that there was no distinction between both genders, and that people do not talk differently from one another (Weatherall, 2002; Mills, 2003).

\section{The Three Waves of Feminism}

Language and gender research objectives were divided into two groups: investigation of dissimilarities between how people talk, and sexist language research (Weatherall, 2002). This classification was the central characteristic of language and gender studies until the twentieth century when there was a change towards examining how men and women are built through language (Litosseliti, 2006). The field of language and gender research has also been firmly associated with women's language because the three waves of feminism affected its advancement. These three waves have influenced the distinctive methodologies linguists utilized for studying gender and, with more focus on feminism today (Mullany \& Mills, 2011). 
There has been some debate about how the first wave of feminism came into existence. According to some researchers Mary Wollstonecraft, the British philosopher and women's rights advocate, is the founder of modern feminism. (Mullany \& Mills, 2011). However, others believe the first wave started in 1848 after the Seneca Falls Wone's Rights convention and lasted until 1920 when the $19^{\text {th }}$ U.S. Constitution Amendment gave women suffrage rights (Hewitt, 2010). The efforts of white middle-class. well-educated women were the pillars of this first wave (Krolokke \& Sorensen, 2006), and it was criticized by the later waves for having limited political objectives (Hewitt, 2010). Nonetheless, the first wave supporters pioneered in addressing issues of how women are perceived by the society as only belonging to home life and expected to talk and act in certain moulded ways. It can be concluded that the primary goal of the first was equity feminism that called for equality between men and women in the society (Krolokke \& Sorensen, 2006).

The second feminist wave was the representation of the women's liberation movement of the 1960s and mid-1970s (Krolokke \& Sorensen, 2006). Unlike the first wave, the second wave the second wave was radical, transformative, and progressive. Rather than having a sole target, second wave activists had a wide range of financial, educational, and political goals (Hewitt, 2010). They called difference feminism which acknowledges that there are differences between men and women. The problem with difference feminism was then that men and women were then treated as two homogenous groups which left no chances for differences among them (Mullany \& Mills, 2011). This led to identity feminism which, according to Krolokke \& Sorensen (2006) raised the issue of having differentiated identities that intersect with gender, class, race, ethnicity, and sexuality. It can be inferred that second wave feminists were the first to address the notion of gender identity being different from the biological gender, which is one of the main features of language and gender studies. It was during that second wave that various language and gender studies took place. (Krolokke \& Sorensen, 2006).

The third wave feminism of the 1990s benefited from the victories of the previous two waves to surface and they considered themselves to be stronger and more capable (Krolokke \& Sorensen, 2006). They used linguistic stereotypes (such as girl) in their battle against sexism (Krolokke \& Sorensen, 2006). Language scholars on the other hand were trying to grow the discipline by creating research that is significantly more assorted in its core interest (Mullany $\&$ Mills, 2011) and feminists were more consumed in their aim for a dynamic transnational, multi-racial and sexual politics (Hewitt, 2010). Modern feminism grew to include worldwide issues not just those of white, middle class, well educated, working women (Hewitt, 2010). Research topics evolved as well, and instead of viewing people as homogenous groups, it started to study the 
differences between those groups. This also involved the investigation of men's language too (Mullany \& Mills, 2011).

The internet had also contributed to the broad outreach of the third wave feminism. It was through the internet that women's activists were able to reach more people and gain more supporters (Krolokke \& Sorensen, 2006). In addition to aiming for future societal improvements, third wave feminists also cherished the work of earlier feminists; they challenged universal womanhood ideologies (Krolokke \& Sorensen, 2006) and some social character influencers such as social class, ethnicity, sexuality, age, gender, and religion (Mullany \& Mills, 2011). These subjects became important for language and gender studies, from which feminism cannot be disregarded.

\section{Theories of gender conversational differences}

The three waves of feminism influenced language and gender research theories. These theories are referred to as the deficit model, the dominance model, and the difference model. For some linguists only the dominance model, and the difference model are acknowledged (Weatherall, 2002; Goddard \& Patterson, 2000). The three models study how women talk in way that is completely different from men. Of the three theories, only the difference model sees those differences from a positive perspective (Litosseliti, 2006). From the deficit and dominance theories perspectives, women's language is weak. However, distinct social backgrounds is the perspective from which the difference model examines genders' conversational language dissimilarities (Cameron, 2014).

The deficit model is the first to tackle language and gender research (Weatherall, 2002; Litosseliti, 2006). In it, males' language is the standard and females' language is the substandard (Weatherall, 2002; Litosseliti, 2006). This was first claimed by Otto Jespersen in 1922 who argued that female's language consisted of constrained vocabulary, basic grammatical structures, and incoherent sentences (Weatherall, 2002; Litosseliti, 2006). Jespersen also claimed that exaggeration and mitigation are common features of women's language (Weatherall, 2002; Litosseliti, 2006). In the deficit model, men were strong individuals who less and work more, while women were weak, shallow, and talkative and are only capable of being housewives (Weatherall, 2002; Litosseliti, 2006).

Language and gender studies expanded amid the second wave of feminism during the 1970s (Mullany \& Mills, 2011). Following the same steps of Jespersen, the sociolinguist Peter Trudgill asserted that the discourse of men and women varies in many societies not just English-speaking ones (Mullany \& Mills, 2011). Trudgill (1974), argued that these differences could be either ones that are not given much importance, such as gestures and facial expressions, or overtly taught to children. In English-speaking societies, the differences between the language 
of men and women were second nature features. Women's language was perceived as more accurate and conservative, while men's language was the opposite. New forms of language tend to originate from men's language as well (Trudgill, 1974). This is because the society sets certain fixated gender social roles for men and women. Women are expected to abide by correct social behaviour all the time which makes them more aware of their social status than men. Men, on the other hand, are expected to show masculinity, that is why they always use forceful language, and talk about strength and power in their conversations to meet the societies expectations (Trudgill, 1974). These propositions; therefore, social and pressure on both genders.

Another strong supporter of the deficit theory is Robin Lakoff who argued that apparent differences between women's and men's language shows in the use of English grammar (Lakoff, 1975). She found differences in the choice and frequency of the use of words and grammatical structures in certain situations (Lakoff, 1975). She also found differences in employing suprasegmental patterns such as intonation in speech. Lakoff concluded that the difference between the language of men and women is clear and undeniable (Litosseliti, 2006). She described the language of women as weak, hesitant, and deficient, while men's language is strong, clear, and concise (Weatherall, 2002). Lakoff related this difference in the language of men and women to women's weaker status in the society, and not to biological gender differences (Weatherall, 2002).

To outline the language difference between men and women, Lakoff (1975) created a list of the common features of women's language. Some of those features are: (1) empty adjectives, such as adorable; (2) tag questions; (3) hedges, i.e., sort of; (4) indirect requests, such as 'will you please close the door?'; (5) rising intonation to turn a speech utterance into a question, i.e., 'you have a cat?'. These distinctive features contributed to the perception of women as more polite in their language use than men (Lakoff, 1975). The findings of Lakoff, and the views of the deficit model theorists were criticized for the lack of logical evidence (Litosseliti, 2006). Also, O'Barr and Atkins (1980) viewed the features listed by Lakoff as women's language as functions of power and not functions of gender (Weatherall, 2002).

The dominance model was concerned with conversation and power relations (Litosseliti, 2006). According to the dominance theory, women were dominated by men in conversations that is why they tended to use powerless language (Weatherall, 2002). Common features of women's language in the dominance model were the use of questions, hedges, qualifiers, and minimal responses, while men tended to interrupt, start, and control topics (Litosseliti, 2006). The feature of interruptions was very controversial among scholars. Zimmerman and West (1975) found that men interrupted more often than women. James and Clarke's research (1993) found no differences at all between the 
language of women and men. Bilous and Krauss (1988) found more interruptions in women-to-women conversations than in men-to-men conversations. As opposed to its antecedent, the dominance theory relied on data to prove and support its claims (Litosseliti, 2006).

The difference model is the third method for studying language and gender. This model is also known as the cultural approach because it assumes that the differences between the language of men and women are due to the cultural and social background, the subcultures, they are brought up in (Litosseliti, 2006). Certain patterns of utterances produced in the conversations of men and women may occur due to childhood separation between genders and single-sex education (Cameron, 2014). So, the different speech styles of men and women are the result of cultural values instilled in them from an early age (Weatherall, 2002). In the difference model, the differences in language use between men and women are looked at from a positive premise (Litosseliti, 2006). It views women as successful interlocutors in their own way (Goddard \& Patterson, 2000) and prefer affiliation in conversations, while men prefer power and status (Goddard \& Patterson, 2000).

Jennifer Coates is the first difference model supporter. Coates (2015) believed that differences in speech styles between men and women are explained by differences in the linguistic environment in which girls and boys were raised. She argues that language is an important part of socialization, and children are raised to interact into culturally approved gender roles through it (Coates, 2015). Coates (2015) also uses the term style to refer to language. She argued that women's style is cooperative while men's style is competitive. To show support, women tend to use minimal responses in their speech; they also tend to ask more questions and gossip. Men, on the other hand, talk more, use swear words, and employ imperative forms to finish tasks. She concludes that in women-to-women conversations powerless minimal responses are used as a powerful and strong sign of solidarity (Coates, 2015).

Deborah Tannen is one of the remarkable supporters of the difference model. Like Coates, Tannen argued that the differences between how genders express themselves in a conversation are due to being raised in different and segregated cultures (Tannen, 1991). Tannen (1991) also argued that the distinctions could be 'defended as logical and reasonable', and that those distinctions must be recognized and understood. According to Tannen's views, men's conversations and interactions include a sense of competition, that each interlocutor tries to dominate and control the others to show power and independence (Tannen, 1991). She adds that in the world of women, conversations are not the same. In women's conversations the system of hierarchy and superiority also exists, but it is not seen as battlefield, but rather a system of social network, support, affirmation, and friendship (Tannen, 1991). Tannen's 
(1991) anatomized conversations of men and women to get a close look at the differences. She discovered that while men's conversations entail solving problems, women's talks include listening to understand and to share their own (Tannen, 1991). That is why women tend to get frustrated with their partners because they never share (Tannen, 1991). Men see this as deprivation of their right to freedom and personal space (Tannen, 1991). Women fail to understand this because in their world sharing experiences, secrets, and problems increases closeness in relationships (Tannen, 1991). Tannen (1991) calls men's talks 'report' because they are direct and brief, while she calls women's talks 'rapport' because of the solidarity and cooperation that dominate their conversations. Tannen (1991) believes that some researchers refuse to admit the differences between men' and women's talk because of the possibility of receiving unequal treatment, especially for women. Denying the differences or proving that men and women are equal should not also be the researchers' goal. Instead, they should focus more on understanding those differences as representatives of two distinct systems of communication. It can be concluded that the deficit model is seen rather old-fashioned. Scholars interested in gender discourse analysis debated the efficacy of the dominance and difference approaches. The difference model has been the most successful because its views gender differences from a positive premise. Also refusing to denigrate women empowered them in many ways.

\section{Politeness and Gender}

Much research has been done on the differences in language use of men and women in conversations. It has been the topic of dispute among different language and gender scholars. One angle of dispute in the difference between how men and women converse was the concept of politeness. It has been long debated that since men dominate conversations, ask questions, interrupt, and disagree, and women show cooperation and solidarity by agreeing, using tag questions and suprasegmental features while speaking to show interest, therefore women are more polite than men (Holmes, 1995). According to Holmes (1995), there are differences between men's and women's talk because their purposes of having conversations are different. For men, a conversation is a way of communicating information or solving a problem. Women on the other hand converse to 'establish, nurture, and develop personal relationships.' These views prevailed during the second wave of feminism. Biological differences, socialisation differences, and power relations are three common reasons why women are perceived as more polite than men. These reasons correspond with the deficit, dominance, and difference models (Holmes, 1995). In the first approach, biological differences play a role in how gender roles are executed through language. Holmes (1995) adds that in the dominance model, it is claimed that the different patterns of socialization play significant role in why women gain, what 
Tannen (1991) referred to as 'rapport', in their conversations, and why men tend to interrupt to dominate the floor. In the difference model, it is believed that men have more social power than men. This allows them to show their power through the linguistic choices they make in conversations. Because of their powerless status, women are forced to be more linguistically polite in interactions (Holmes, 1995). Brown and Levinson (1987) defied this opinion by arguing that, in case of women, the polite linguistic features in their talk are their strategy of expressing themselves uniquely from men.

Mills (2003) and other third wave feminists argued the beliefs of the first and the second waves. Gender affects linguistic utterances of men and women, and these effects must be analysed in terms of not just the biological differences, but also factors such as religion, social background, education, class, and ethnicity (Mills, 2003). Mills (2003) also argued that it is important to examine the stereotypes that people make, in addition to the previously mentioned factors, because they affect how people make linguistic choices, and how they receive the choices others make in interactions. Because women are not as socially powerless as they were in the past, claiming that their language is weak, or they are powerless interlocutors falls under gender essentialism (Mills, 2003). Examining speech features that are perceived masculine or feminine; hence powerful or powerless, should not be done from the scope of gender as a binary system in language and gender research (Mills, 2003).

\section{Data}

\section{Methodology}

The study will use extracts from three Disney movies from three different periods of time. The films are Snow White and the Seven Dwarves (1937), Beauty and the Beast (1991), and Tangled (2010).

\section{Snow White and the Seven Dwarves (1937)}

Snow White and the Seven Dwarfs (1937) tells the story of a lonely princess, Snow White, who lives with her father, the King, and her stepmother, the Queen. The Queen, out of jealousy, forces Snow White to work with the maids in the kitchen because she was worried that Snow White would become more beautiful than her. Obsessed with beauty and desiring to be the most beautiful woman in the kingdom, the vain Queen owns a magic mirror that she asks every day about the fairest one in the kingdom, and the mirror always replies that the Queen is. One day, the Queen asks the mirror who the most beautiful woman is, and the mirror replies that Snow White is. Enraged and angered, the Queen orders the Huntsman to take Snow White to the forest to kill her then bring back her heart as proof of obeying the Queen's order. Unable to fulfil the Queen's wish of killing princess Snow White, the Huntsman cries and begs the princess for 
forgiveness, and reveals to her the Queen wants her dead. He tells her that she must escape to save her life. Snow White runs into the woods, and befriends some animals that sooth her, and ease her feelings of loneliness and anxiety, then take her to a small cottage located deep in the forest to sleep and rest in it. Snow White first assumes that it is an abandoned place, but as soon as she enters, she realizes that it is not. Snow White then starts to explore the place; finding seven small chairs, and seven small beds, she assumes that this cottage is the home for seven orphaned children, and it is unclean for that reason. With the help of the forest animals, Snow White cleans the cottage then falls asleep out of tiredness. Seeing the cottage lights from afar, the seven dwarfs are alarmed, and they suspect there is a thief or an evil intruder in their house. They summon their courage then enter the cottage, only to find it tidy and clean. Amazed by what they have seen, they enter the room to find Snow White sleeping in it. As soon as she wakes up, she finds them all standing in front of her. She introduces herself to them, then asks them to allow her to stay with them and she would keep the house and cook for them, while they go to the mine where they work. In the meantime, the Queen continues to ask the mirror about the fairest woman in the kingdom, and she realizes that Snow White is still alive when the mirror replies that Snow White is the fairest. The Queen then demands the presence of the Huntsman who, after she interrogates him, admits that the heart he gave her was that of a pig. The Queen then uses her magic to know where Snow White is. She plans to kill her by making her eat a poisoned apple. The Queen locates Snow White, then dresses up as an old poor woman then goes to the dwarfs' cottage where Snow White stays. She reaches the cottage and offers Snow White the apple, that she claims would make her marry the love of her life. The animals try to warn Snow White. Scared that her plan might be ruined, the disguised Queen fakes sickness so that Snow White would let her in, where she makes her eat the apple. Snow White faints as soon as she eats it. The dwarfs return to find that Snow White is almost dead. They put her in a glass bed hoping that one day she would wake up from her long sleep. The Prince, whom she met before, visits her. Saddened by how she ended up he kisses her, which breaks the spell and awakens the sleeping princess. The dwarfs and the animals celebrate her coming back from death, and the Prince takes her to his castle where they will get married and live forever.

\section{Beauty and the Beast (1991)}

The movie starts with a cold rainy night. A very old beggar woman seeks solace at the prince's castle in exchange for a flower, all that she has. The Prince refuses and sends the beggar, in a cruel manner, out of his castle. The woman, who happens to be an enchantress, reveals her identity as soon as he does, and casts a spell on him and the whole castle including its inhabitants, and transforms the Prince into a beast as a punishment for his cruelty and arrogance. The spell can only be broken if the Prince, now a beast, learns to love and be truly loved in 
return before the last petal of the flower falls or else, he will remain a beast forever. Years later, in a neighbouring village, lives Belle, and her father Maurice, an inventor. Belle is a minimalist who loves reading and dreams of an adventurous life; one like the ones she reads about in books. Belle happens to be admired by Gaston, a narcissistic hunter, who only wants to marry Belle because she is beautiful. On his way to an exhibit where he is going to showcase his latest invention, Maurice - Belle's father, gets lost in the forest and attacked by some wolves, too many that his horse runs away. Seeing the castle, he enters to seek solace from the cold and the rain. The beast is angered to see him and decides to imprison him for life for trespassing. When the horse returns to village without Maurice, Belle decides to go look for her father. She finds him locked in the dungeons of the castle and pleads for the beast to free him. He agrees under the condition that she stays instead of him. Belle agrees, so the Beast tells her that she free to roam the castle except for the west wing. She then befriends the servants of the castle and starts to wonder about what is in the west wing, but they never speak of it. Driven by curiosity, Belle enters the west wing, then Beast catches her and angrily orders her out. Scared for her life, she not only leaves the west wing, but also the entire castle. In the woods, as she is trying to get back to the castle, she is ambushed by wolves, but the Beast goes after her and saves her from them, and he gets injured in the process. Belles nurses his injuries and cleans all wounds in return for the favour. Soon, affection starts to grow between Belle and the Beast then they fall in love for each other. In the village, Maurice is trying to tell everyone about the Beast and that he has his daughter imprisoned in his castle, but no one believes him. Hearing of the news, Gaston plans along with the asylum's warden to lock Belle's father in the asylum, so that when Gaston goes for the rescue, Belle would have no chance but to agree to marry him. After a romantic dinner with the Beast, Belle wanders about her father so the Beast gives her a magic mirror that she can looks at to see him. Worried about his condition, Belles pleads to leave to go help him. Gaston then locks them both in the basement and tells the villagers that there is a Beast in the forest that it might attack them, so they must take it down. They all rush to the castle with Gaston to kill the Beast. Belles manages to escape to help him but when she arrives, Gaston has already attacked the Beast and he is severely wounded. Gaston on the other hand has been defeated and fell off the castle's tower. The Beast dies in Belle's arms the same moment the last petal if the magic flower falls off. Belle confesses she loves him which breaks the spell. The Beast comes back to life but as the handsome Prince he was along with all the servants of the castle and the castle itself. The movie ends with Belle and the Prince hosting a celebration party in the castle where everyone is dancing and happy. 


\section{Tangled (2010)}

In an isolated area, lives a woman who uses an enchanted flower to preserve her youth and beauty. The flower came from a drop of liquid sunlight, and it has been used by this woman, called Gothel, for years. The soldiers of the King plucked the flower to rescue the Queen who is suffering pregnancy problems. Soon afterward the Queen gives birth to young girl, whose hair happens to have the healing powers of the magic flower. Knowing that, Gothel sneaks to the castle to cut a lock of Rapunzel's hair. By doing so, Gothel discovers that cutting a lock from the girl's hair only renders its powers, so she decides to abduct the girl. She takes her to a secret place, a tower in the middle of the forest in an abandoned area, where she raises the girl as her daughter. To keep the girl inside the tower, Gothel tells her that the world is cruel place, and that if he ever steps out, she is going to get hurt or even killed. Ever since she disappeared, Rapunzel's parents - the King and the Queen, have been flying lit up lanterns on their daughter's birthday, hoping that one day she would see them and come back. From her tower, Rapunzel has grown up watching those lanterns in the sky on her birthday. She senses that those lanterns mean something for her, and she pleads for Gothel to let her go, on the night of her eighteenth birthday, to discover them now that she is grown up and can protect and defend herself. Gothel refuses and tries to sway her from the thought. Meantime in the kingdom, the lost princess's crown is stolen by a thief called Flynn Rider, who takes it for himself and ditches his other partners. Flynn escapes to the forest and seeks refuge in the tower where Rapunzel and Gothel live thinking it were an abandoned place. Rapunzel knocks him down as soon as he enters. Not knowing what to do, so she puts him in the closet until Gothel returns. When she is back, Rapunzel tries to talk to her to show her Flynn to prove that she can take care of herself, but Gothel dismisses her, then changes the subject to embarking on a three-day trip to get Rapunzel a special type of paint for her eighteenth birthday. After she is gone, Rapunzel hides the crown Flynn stole as well as his satchel. She then brings him out of the closet and tries to wake him up to converse with him. She makes a deal with him, that if he agrees to take her see the flying lanterns, she will give him his belongings back. Flynn agrees and it turns out to be an unforgettable experience for her.On her way, Mother Gothel encounters Maximus, one of the royal horses leading the soldiers that are on mission to find the princess's stolen crown. Worried about the soldiers finding her tower and the abducted princess, Gothel returns to check on Rapunzel only to find her gone, and she discovers the satchel and the stolen crown, so she goes after her to find her. In the meantime, the adventures of Flynn escaping bring him and Rapunzel close and they start to fall in love with one another, and they start confiding in one another. Flynn reveals to her his real name, Eugene Fitzherbert, and Rapunzel reveals that her hair glows when she sings. Maximus later finds Flynn and tries to arrest him, but Rapunzel makes a deal with the horse to let him go for just one day until he, Flynn, takes her to see 
the flying lanterns. Maximus agrees and Flynn fulfils his promise. On a small boat, with the flying lanterns in the background, Rapunzel and Flynn confess their love for one another, but as soon as Flynn was about to kiss her, he notices the Stabbingtons, his partners in the theft of the crown from the King's palace, so he excuses for a couple of minutes. His plan is to give them the crown and apologize, but they hit him and tie him to a boat so that Rapunzel would assume he abandoned her. This was all planed by Gothel how was watching the couple from a far. Feeling abandoned and lonely, Rapunzel starts crying but Mother Gothel suddenly appears and takes her back to the tower. As for Flynn, he gets arrested by Maximus, and is imprisoned as a punishment for his crime.Back in the tower, Rapunzel starts to link the symbol of the kingdom to that shape she subconsciously drew on the walls of the tower. Now that she knows the story of the lanterns, she connects the dots and realizes that she is the long-lost princess. She confronts Gothel, who does not deny, and claims that all that she had done was for Rapunzel's good. Enraged, Rapunzel attempts to leave the tower, but Gothel prevents her. With the help of Flynn, Gothel is defeated, and the princess is rescued and returns to her mother and father after long years of separation, and like all Disney films, the ending is a happy one. Flynn and Rapunzel get married and they live happily forever.

\section{Tools}

\section{Women's Language Features}

To trace the change in language use and nonverbal reactions from Snow White to Rapunzel, the current research explores the language of the heroines of the following three movies: Snow White and the Seven Dwarfs (1937), Beauty and the Beast (1991), and Tangled (2010). With regards to the aim, the study will compare the speech of the female subjects in these movies against the prevailing ideas language and gender research to examine the prospective linguistic shift from quantitative and qualitative perspectives. Gathered below is a list of seven of women's language characteristics, which are the study's quantitative/ qualitative focus, presented in the theoretical section. They are as follows: (1) Talkativeness; (2) Indirect Requests; (3) Interrupting; (4) Imperative Forms; (5) Shouting; (6) Threats and Insults; and (7) Disagreeing. 


\section{Analysis and Discussion}

Women's Language Features

Table 1

Female Language Features Results

\begin{tabular}{|c|c|c|c|}
\hline Character & $\begin{array}{c}\text { Snow White } \\
\text { (1937) }\end{array}$ & $\begin{array}{c}\text { Belle } \\
(1991) \\
\end{array}$ & $\begin{array}{c}\text { Rapunzel } \\
(2010)\end{array}$ \\
\hline Feature & \multicolumn{3}{|c|}{ Frequency } \\
\hline 1. Talkativeness & $\begin{array}{c}1,239 / 4,149 \\
(29.8 \%)\end{array}$ & $\begin{array}{c}1,190 / 8,165 \\
(14.5 \%)\end{array}$ & $\begin{array}{c}2,208 / 6,224 \\
(35.4 \%)\end{array}$ \\
\hline 2. Indirect Requests & 2 & 5 & 1 \\
\hline 3. Interruptions & 1 & 2 & 12 \\
\hline 4. Imperatives & 32 & 17 & 72 \\
\hline 5. Shouting & 0 & 7 & 12 \\
\hline 6. Threats \& Insults & 1 & 9 & 0 \\
\hline 7. Disagreeing & 5 & 26 & 34 \\
\hline
\end{tabular}

\section{Talkativeness}

In its language and gender research, the deficit model characterizes women's language with some features such as mitigation, exaggeration, hedges, and talkativeness. This model views women as talkative conversationalists capable only of being housewives. In the difference model, women are seen to talk more because in women-to-women conversations talking is done to show solidarity. Talkativeness then is seen as a powerful feature of women's language. The feature of talkativeness is also one of the features that varies significantly among the three heroines at hand. Table 1 shows the number of words spoken by each of them. Numbers demonstrate that there is a gradual increase in the number of words in each of the characters' talk. Contrary to expectations, this gradual increase indicates that modern time heroine, Rapunzel, is the most talkative. Below are three extracts from the three princesses' utterances to show talkativeness in operational function. 


\section{Example 1. Snow White and the Seven Dwarfs (1937)}

Snow white enters what she thought was an abandoned cottage in the forest. She asks for permission to come in just in case someone is in, then she starts to explore the place.

Hello? May I come in? Oh! What a cute little chair! Why, there's seven little chairs! Must be seven little children. And from the look of this table, seven untidy little children. A pickaxe. A stocking, too! And a shoe! And just look at that fireplace. It's covered with dust. (Snow White, 1937, $00: 15: 51)$

\section{Example 2. Beauty and the Beast (1991)}

After he set off for the exhibit to show off his invention, Maurice - Belle's father, gets lost in the forest. His horse, Philipe, runs away back home in escape from the wolves that attacked the cart and Maurice enters a castle to find solace from the cold and the rain. Seeing Philip has returned alone, Belles decides to go look for her father. She finds the castle and decides to go in.

Hello? Is anyone here? Hello? Papa? Papa? Are you here? Papa? Papa? Papa? Hello? Is someone here? Wait! I'm looking for my father That's funny, I'm sure there was someone. Is there anyone here? Papa! Oh, your hands are like ice. We have to get you out of here. Who's done this to you? I won't leave you! (Belle, 1991, 00:21:45)

\section{Example 3. Tangled (2010)}

Rapunzel has grown up watching the flying lit lanterns her parents, the King and the Queen, have been flying each ear on their lost daughter's birthday. She feels that she is connected to those lanterns somehow and that they mean something for her. On her birthday, she asks Mother Gothel, the woman who abducted her when she was a baby and thinks she is her mother, to allow her to go see them.

So, mother, earlier I was saying that tomorrow was a pretty big day, and you didn't really respond, So I'm just going to tell you. It's my birthday! TADA! That's the funny thing about birthdays. They're kind of an annual thing. Mother, I'm turning eighteen. And I wanted to ask, what I really want for this birthday. Actually, what I want for every birthday. Oh, I want to see the floating lights. (Rapunzel, 2010, 00:11:26)

\section{Indirect Requests}

The deficit model is concerned with studying the linguistic differences between men's and women's speech. Many of its researchers found that 
mitigation is one of the common features of women's language, from which it can be inferred that women are more polite than men. As demonstrated earlier in Table 1, and unexpectedly so, Belle from Beauty and the Beast (1991) used more polite requests than others -with a total of five. Snow White used only three while Rapunzel used polite request in one single utterance. The following are extracts from the three princesses' utterances to show how they implemented indirect requests in their speech.

\section{Example 1. Snow White and the Seven Dwarfs (1937)}

In this utterance, Snow White is asking the animals to take here somewhere to sleep after the Huntsman let her escape. Even though she was talking to forest animals, she still employed mitigation in her speech.

"Maybe you know where I can stay." (Snow White, 1937,00:14:4).

\section{Example 2. Beauty and the Beast (1991)}

Here, Belle is asking Lumiere and Cogsworth, two of the enchanted inhabitants of the castle and servants of the Beast, to tour her around the castle. She is very excited to be in an enchanted place like the ones she reads about in books. It can be noticed that Belle politely asked them to wander her around even though she knew they were servants of the Prince before the Enchantress casts her spell on the whole castle.

"Perhaps you would like to take me. I'm sure you know everything there is to know about the castle." (Belle, 1991,00:43:11).

\section{Example 3. Tangled (2010)}

Instead of asking to go see the floating lanterns by herself, Rapunzel opts for mitigating her request by seeking her mother's company to the place of the event. She knew how protective her mother is, and that she doubts her daughter would be able to protect herself when she goes out. So, Rapunzel employs mitigation in order to gain her Mother Gothel's approval.

"Well, I was hoping you would take me to see the floating lights." (Rapunzel, 2010, 00:12:16).

\section{Interruptions}

This feature is linked with conversational power relations which is the main concern of the dominance model. The feature of interrupting is a masculine trait employed by men to show dominance in conversations. Today, men and women are seen to be talking nearly the same, and that interruption is not a masculine feature of speech but rather a powerful one regardless of the gender 
(James \& Clarke, 1993). Examining the speech of the three princesses found that they used the feature in their speech. The frequency of interruptions increased over time, making the modern time princess Rapunzel the most frequent interrupter.

\section{Example 1. Snow White and the Seven Dwarfs (1937)}

The only interruption attempted by Snow White is this. The Dwarfs came back from their work at the mine very hungry, and they were excited to see that the Princess had cooked supper. Excited, they all run and sit by the dinner table. They are then interrupted by Snow White who announces that food would be ready as soon as they finish washing up.

"Snow White: Soup!

The Seven Dwarfs: Hooray! (chattering, all sit at the table arguing)

Snow White: (interrupting) Uh-uh, uh-uh! Just a minute. Supper's not quite ready. You'll just have time to wash." (Snow White, 1937, 00:39:50)

\section{Example 2. Beauty and the Beast (1991)}

Jealous because Belle had refused to marry him and fell in love with the Beast, Gaston gathers the townsfolk to follow him to kill the Beast. Hearing him tell lies about what the Beast would do to them and their children, Belle interrupts Gaston to discourage the angry and scared mobs. This is one of the two interruptions made by Belle.

Gaston: She's as crazy as the old man. The beast will make off with your children! He'll come after them in the night.

Belle: (interrupting) No!

Gaston: We're not safe 'til his head is mounted on my wall! I say we kill the beast! (Belle, 1991, 01:11:32)

\section{Example 3. Tangled (2010)}

The most frequent interrupter is Rapunzel, with twelve instances made as part of her speech in the film. Driven by her will to see the flying lanterns, she tries to persuade Mother Gothel to let her go see them. Gothel knows that if Rapunzel leaves that tower, she will know that truths that is why she keeps on refusing her request. 
Mother Gothel: Oh darling, I know you're not strong enough to handle yourself out there-

Rapunzel: (interrupting) But if you just... (Rapunzel, 2010, 00:22:58).

\section{Imperatives}

According to Coates (2015) men's speech style is characterized by force and power. This is because men are competitive interlocutors, while women are cooperative. One way men show this is by using imperatives. Because of being regarded as cooperative speakers, women tend to use minimal responses and other powerless signs of language to maintain the conversation and show solidarity. The results in Table 1 show that the most frequent use of imperatives was made by Rapunzel with a total of 72 instances. The second one to use imperatives, and unexpectedly so, is Snow White. This could be because of the power of her status as a princess which had also been perceived highly by the Seven Dwarfs since their first encounter with her. Belle comes last in the list with 17 imperatives total. Imperatives, the most dominant in the data, were used to give a wide range of commands. They were also part of the princesses' songs.

\section{Example 1. Snow White and the Seven Dwarfs (1937)}

This part of a conversation between Snow White and the Dwarfs. The princess realized that the last time ever washed was long ago. Here, she is urging them to wash their hands or else she will not serve supper. Snow White, unexpectedly, used 32 imperatives. This could be due to the fact that she was honoured and respected by the Dwarfs as the kingdom's Princess so she acted accordingly.

"March straight outside and wash or you'll not get a bite to eat." (Snow White, 1937, 00:41:29)

\section{Example 2. Beauty and the Beast (1991)}

This is an example of one of the 17 imperatives used by Belle. In this conversation power is at the Beast's side because of his physical power and because of having her father prisoned in in his castle's dungeons. Belle did not care much about that because her goal was to free her old father. The Beast told her that this could happen only if she agrees to stay instead of him. This is when she asked him to come into the light so that she sees with whom she would be spending the rest of her life.

"Come into the light." (Belle, 1991,00:24:06) 


\section{Example 3. Tangled (2010)}

In this example, Rapunzel shows resistance and stamina to continue her trip to the flying lanterns. Flynn, the stray thief who stole the lost princess's crown from the King's castle and sought solace in Rapunzel's tower assuming that it was an abandoned place, agreed to take Rapunzel to where they fly the lit lanterns under the condition that she gives him back the crown that she hid in the tower. He took her to the pub where all the ruffians and thieves spend time in order to make her change her mind. Some of them attack Flynn so Rapunzel stands up for him.

“Give me back my guide! Ruffians!” (Rapunzel, 2010, 00:38:22)

\section{Shouting, Threats and insults, and Disagreeing}

Verbal aggression is a significant feature of men's language, (Coates, 2015), while women are more polite speakers because this is how they express themselves in a way different from men (Brown \& Levinson, 1987). The feature of shouting is another significant characteristic prevailing the speech of Rapunzel the most. Shouting is used in situations with heated arguments and important events. Apart from Snow White, Rapunzel has 12 instances while Belle only 7. Threats and insults were found 9 times in the speech of Belle, however, Snow White used it once, and surprisingly Rapunzel had none. As for disagreeing, it was employed prominently by Rapunzel and Belle: 34 and 26 instances, respectively. Snow white has only 5 instances of disagreeing which makes it the lowest number of disagreeing usages in the speech of the three heroines.

\subsection{Shouting}

Shouting is usually tied to a certain situation. In example 1 Belle is seen shouting at the Beast while she cleans the wound he got when he defended her against the wolves that attacked her in the forest when she had left the castle. In this conversation Belle shouted back at him when he was already shouting, blaming her to be the reason why he got the wound by deciding to leave. Belle did not shy away or show signs of subordination. Instead, she shouted back and defended her stance proving that shouting is not a gender specific feature of language.

\section{Example 1. Beauty and the Beast (1991)}

"Belle: If you'd hold still, it wouldn't hurt as much." (Belle, 1991, 00:49:42) 


\section{Example 2. Tangled (2010)}

Of the 12 instances of shouting in Rapunzel's speech this one is the most important. She confronts Gothel with the truth. Shouting "I'm the lost Princess" was her way to make this revelation, and to show resistance against all that Gothel can enforce from then on, providing another proof that shouting is not exclusive to men's talk.

"Rapunzel: I am the lost Princess." (Rapunzel, 2010, 01:17:58)

\subsection{Threats and insults}

The only instance where Snow white may have used an insult in her speech is when she talked to Grumpy. This Dwarf did not like the Princess at all and was against hosting her in the cottage in fear of the evil Queen. Whenever she spoke to him, he did not answer. In the following example Snow White's utterance can seem as an insult; however, as far as the authoritative power as a princess is concerned, this utterance may not be seen as a face threatening act but rather an attempted funny joke.

\section{Example 1. Snow White and the Seven Dwarfs (1937)}

"Snow White: What's the matter? Cat got your tongue?" (Snow White, 1937, 00:42:15)

\section{Example 2. Beauty and the Beast (1991)}

"Belle: Gaston, you are positively primeval." (Belle, 1991, 00:8:52)

\subsection{Disagreeing}

The last feature in this category is disagreeing. It is rather predominant in the speech of Belle and Rapunzel. By employing disagreeing in their speech, the princesses can provide a good example of strength and resistance to young girls. In the following example, Snow White did not disagree on something said by the Dwarfs, but rather on the fact that they were ready to sit to eat supper without washing their hands.

\section{Example 1. Snow White and the Seven Dwarfs (1937)} 00:41:26)

"Snow White: Goodness me, this will never do." (Snow White, 1937,

\section{Example 2. Beauty and the Beast (1991)}

In this utterance Belle disagrees with Wardrobe, enchanted opera singer, on having dinner with the Beast. That was Belle's first night at the castle and that 
was her way to show independence and resistance to anything that the Beast tries to enforce on here.

"Belle: I don't want to get to know him. I don't want to have anything to do with him!"

(Belle, 1991, 00:36:29)

\section{Example 3. Tangled (2010)}

Flynn was trying to use Rapunzel's hesitance after leaving the tower for the first time and attempted to sway her mind. He offered to walk her back to the tower, but she came back to her senses and decided to embark on her trip.

"Rapunzel: No, I am seeing those lanterns." (Rapunzel, 2010, 00:33:56)

\section{Conclusion}

To conclude, this paper examined the shift in the language of three Disney princesses from three films produced in three different periods of time. The aim was to discover whether the language of the three princesses included feminine features in a progressive manner throughout the films across the three eras. The material for the research consisted of the scripts of the three films, and the methods were to analyse seven of the features of women's language in a quantitative-qualitative method. Results show that the language of the princesses have become more forceful. Features that were regarded as men's language exclusive features prevailed in the languages of Belle (Beauty and the Beast, 1991) and Rapunzel (Tangled, 2010). There is an undeniable substantial degree of variation of instances across the results of the three females. Results of this research corroborate results by England (2011) and Kirjavainen (2013) who concluded that the depiction of Disney Princess has become more sophisticated and complex, and that this depiction contributes to children's understanding of gender roles. Due to the limitations of this research, the study included only three films and focused on the three female leading characters. It would be interesting to see papers comparing between the male and the female leading characters of the films. It might also focus on the verbal and the nonverbal reactions of the chosen characters. 


\section{References}

Bilous, F. R., \& Krauss, R. M. (1988). Dominance and accommodation in the conversational behaviours of same-and mixed-gender dyads. Language \& Communication.

Brown, P. and Levinson, S.C. (1987). Politeness: Some Universals in Language Usage. Cambridge: Cambridge University Press.

Cameron, D. (2014). The language-gender interface: challenging cooptation (pp. 31-53). Routledge.

Coates, J. (2015). Women, men and language: A sociolinguistic account of gender differences in language. Routledge.

Cook, J., \& Main, W. (2008). What is a princess? Developing an animated TV program for small girls. Australian Feminist Studies, 23(57), 401-415.

Do Rozario, R. A. C. (2004). The princess and the magic kingdom: Beyond nostalgia, the function of the Disney princess. Women's Studies in Communication, 27(1), 34-59.

England, D. E., Descartes, L., \& Collier-Meek, M. A. (2011). Gender role portrayal and the Disney princesses. Sex roles, 64(7), 555-567.

Forgacs, D. (1992). Disney animation and the business of childhood. Screen, 33(4), 361-74.

Forman-Brunell, M., \& Eaton, J. (2009). The Graceful and Gritty Princess: Managing Notions of Girlhood from the New Nation to the New Millennium. American Journal of Play, 1(3), 338-364.

Goddard, A., Patterson, L. M., \& Mean, L. (2000). Language and gender. Psychology Press.

Gray, J. 1994. Men Are from Mars, Women Are from Venus. New York: Harper Collins.

Hewitt, N. A. (ed.) 2010. No Permanent Waves: Recasting Histories of U.S. Feminism. New Brunswick, NJ: Rutgers University Press.

Holmes, J. (1995). Women, Men and Politeness. London: Longman.

James, D., \& Clarke, S. (1993). Women, men, and interruptions. Gender and conversational interaction, 231-280. 
Kirjavainen, P. P. (2013). Mirror m'/irror on the wall, who's the bluntest of them all?: Linguistic shift from Snow White to Rapunzel (Master's thesis, Itä-Suomen yliopisto).

Krolokke, C. and Sorensen, A.S. 2006. Gender Communication Theories and Analyses: From Silence to Performance. Thousand Oaks, California: Sage Publications, Inc.

Lakoff, R. (1975). Language and Woman's Place. New York: Harper \& Row.

Litosseliti, L. (2006). Language and Gender: Theory and Practice. London: Hodder Education.

Mills, S. (2003). Gender and politeness (Vol. 17). Cambridge University Press.

Mullany, L., \& Mills, S. (2011). Language, Gender and Feminism: Theory, Methodology and Practice. Routledge.

O'Barr, W. M., \& Atkins, B. K. (1980). " Women's language" or" powerless language"?.

Orenstein, P. (2006). What's wrong with Cinderella. The New York Times, 6(1), 34.

Stover, C. (2013). Damsels and heroines: The conundrum of the post-feminist Disney princess. LUX: A Journal of Transdisciplinary Writing and Research from Claremont Graduate University, 2(1), 29.

Tannen, D. 1991. You Just Don't Understand: Women and Men in Conversation. New York: Morrow.

Trudgill, P. (1974). Sociolinguistics: An Introduction. Harmondsworth: Penguin Books.

Weatherall, A. 2002. Gender, Language and Discourse. Hove: Routledge.

Wilde, S. (2014). Repackaging the Disney princess: A post-feminist reading of modern day fairy tales. Journal of Promotional Communications, 2(1).

Zimmerman, D. H., West, C., Thorne, B., \& Henley, N. (1975). Language and sex: Difference and dominance. 